\title{
THE EFFECT OF UNCERTAINS IN EUROPEAN ECONOMIC POLICIES ON THE BIST 100 INDEX*
}

\author{
Avrupa Ekonomi Politikalarındaki Belirsizliklerin BIST 100 Endeksi \\ Üzerindeki Etkisi
}

Saffet AKDAĞ $^{* *}$ \& Hakan YILDIRIM ${ }^{* *}$

\begin{abstract}
Uncertainties are one of the factors affecting investors' investment decisions.

Keywords:

Economic Policy Uncertainty Index, BIST 100 Index, Causality Analysis, Cointegration Analysis, FMOLS and DOLS

JEL Codes: C22, D80, G12, G23 In accordance with the wait-and-see policy, which is the best option for investors in an uncertain environment, investors can postpone their investment and consumption decisions. Uncertainties especially in economic policies affect investors' decisions more deeply. In this context, the goal of this study is to test the effect of European Economic Policy Uncertainty (EPU) index, which represents uncertainties in economic policies of European countries, on BIST 100 index by Vector Error Correction Model (VECM), Johansen Cointegration and cointegration coefficient estimator FMOLS and DOLS. Monthly data between February 1988 and May 2019 were used in this study. Findings of the study, it was reached that there was a long-run interaction between EPU and BIST 100 index and the increases in the EPU index had a negative effect on the BIST 100 index. In addition, oneway causality relationship was determined from the change in EPU index to the change in BIST 100 index.
\end{abstract}

Anahtar Kelimeler: EPU, BIST 100,

Nedensellik Analizi, Eşbütünleşme Analizi, DOLS ve FMOLS

JEL Kodları: C22, D80, G12, G23

\section{Öz}

Belirsizlikler, yatırımcıların yatırım kararları üzerinde etkili olan faktörlerden biridir. Belirsizliklerin olduğu ortamda yatırımcılar için en iyi seçenek olan bekle-gör politikası gereğince yatırım ve tüketim kararlarını erteleyebilmektedirler. Özellikle ekonomi politikalarında yaşanan belirsizlikler, yatırımcıların kararlarını daha derinden etkilemektedir. Bu bağlamda bu çalışmada Avrupa ülkelerinin ekonomi politikalarındaki belirsizlikleri temsil eden Avrupa ekonomik politika belirsizlik (EPU) endeksinin BIST 100 endeksi üzerindeki etkisinin Vektör Hata Düzeltme Modeli (VECM), Johansen eşbütünleşme testi ve FMOLS ve DOLS tahmincileri ile test edilmesi amaçlanmıştır. 02/1988 - 05/2019 dönemi aylık verilerin kullanıldığı analiz sonucunda EPU ile BIST 100 endeksi arasında uzun dönemli bir ilişki olduğu ve EPU endeksinde meydana gelen artışların BIST 100 endeksi üzerinde negatif etkisinin olduğu tespit edilmiştir. Ayrıca EPU endeksindeki değişimimen BIST 100 endeksindeki değişime doğru bir nedensellik ilişkisinin olduğu ve bu nedenselliğin tek yönlü olduğu tespit edilmiştir.

\footnotetext{
* The manuscript was orally presented in Turkish within the scope of the 6 . International Congress on Accounting and Finance Research.

** Assoc. Prof. Dr., Tarsus University, Faculty of Applied Sciences, Department of Finance and Banking, saffetakdag@tarsus.edu.tr , ORCID: 0000-0001-9576-6786

** Assist. Prof. Dr., İstanbul Gelişim University, Faculty of Economics, Administrative and Social Sciences, Department of Logistics Management, hayildirim@gelisim.edu.tr, ORCID: 0000-0002-32712841
}

Makale Geliş Tarihi (Received Date): 10.01.2021 Makale Kabul Tarihi (Accepted Date): 08.04.2021 


\section{S. Akdağ \& H. Yıldırım, "The Effect of Uncertains in European Economic Policies on the BIST 100 Index"}

\section{Introduction}

People make most of their decisions under uncertainty. Therefore, determining the effects of uncertainties on decision processes has been the focus of attention of researchers (Liu, 2010, p. 1). Since uncertainties in the field of economy affect all segments of the society, they are carefully followed by both financial authorities and market players. Theoretically, in a period of increased uncertainty, the best option for investors is a wait-and-see policy. Therefore, investors can postpone their investment decisions in an environment of uncertainty. Production and employment will be negatively affected from this situation (Bernanke, 1983; Bloom, 2009). On the other hand, as the uncertainties increase, the risk-driven costs of financial institutions that provide loans will increase, this will cause the interest rates to increase, and the increasing fund costs due to the interest rate increase will have negative effects on the investment decisions of the companies (Cerda, Silva and Valente, 2018, p. 2894). As a matter of fact, the uncertainties that emerged in the financial markets due to the magnitude and continuity of the Great Depression in 2008 caused serious adverse effects both on the spending decisions of consumers and on the investment decisions of businesses all over the world (Baker, Bloom, and Davis, 2016).

Most of the uncertainties in the field of economics stem from the decisions taken or not taken by the financial authorities. In this context, various indices are created to measure uncertainties in the economy. One of these indices, EPU; It is an index developed in the paper of Baker et al. (2016) and based on the analysis of media content. EPU is calculated separately for 23 countries, especially in the world and Europe. In this study, the short and long-term relationship between EPU and the BIST 100 index is tested with the Engle and Granger (1987) vector error correction model (VECM), while the long-term relationship also is tested with the Johansen cointegration method. DOLS and FMOLS coefficient estimators were also used to find the direction of the interaction between EPU and BIST100 used. The study contains five chapters. In the first chapter, the subject is introduced and the next chapter consists of the literature that includes similar studies that have been done before. In the third and fourth sections, the data and methodology used in the study and the findings related to the analysis are presented, respectively. In the last part, there is a general evaluation and recommendations.

\section{Literature}

Kang and Ratti (2013), one of the first studies to test the interaction between stock market indices and EPU, stated that uncertainties in US economic policies negatively affected stock market indexes. In the study of Li, Zhang and Gao (2015), another study conducted specifically for the USA, it was stated that the shocks caused by the uncertainties in economic policies negatively affected the stocks. A similar study is Bayar and Aytemiz (2015). In the study using data from European Union countries, a causality relationship from uncertainty in economic policies to stock market indices could not be determined. Similarly, in Donadelli (2015), where the interaction between the stock market index of ten Asian countries and the uncertainties in the economic policies of the USA was tested, no causality relationship was found. The investigation of Baker et al. (2016) is one of the first studies investigated on the interaction between share market indexes and EPU. In the study, it was determined that there is a links between the EPU, which is created by scanning the words containing uncertainty from national newspapers and the volatility of stock prices. In the study of Wu, Liu and Hsueh (2016), in 
which the causality relationship between EPU and stock market indices of ten selected countries was tested, a causality relationship was found from EPU to the stock market indices only for the United Kingdom. As a result of the study of Chen, Jiang, Liu and Tu (2017), in which the impact of uncertainties in China's economic policies on stock market indexes was tested, it was stated that the related uncertainties negatively affected the stock market indexes. Similarly, in the study conducted by $\mathrm{Hu}$, Kutan and Sun (2018) specific to China, it was determined that the shocks occurring in EPU of the USA had a reverse effect on stock market indexes of China. Korkmaz and Güngör (2018) stated that the global EPU had a negative effect on Borsa Istanbul (BIST) indices. Similarly, in the study of Tiryaki and Tiryaki (2019) where BIST indices were used, it was concluded that EPU of the USA negatively affected the BIST stock market indices. In the study of Chiang (2019), data from G7 countries were used. It was stated that the EPU of the relevant countries negatively affected the stock market indices. In the Jeon (2019) study conducted in Korea in the same year, it was indicated that the US EPU index had a reverse impact on Korea's stock market indices. In Akdağ (2020) study, the causality relationship between the economic policy uncertainty index and confidence indices of 16 countries, including 13 OECD member countries and 3 non-OECD countries, was tested with panel causality analysis. As a result of the analysis, it was determined that uncertainties in economic policies are the cause of confidence indices. Matkovskyy, Jalan and Dowling (2020) tested the relationship between economic policy uncertainty, Bitcoin and five different stock indices. The findings obtained in the study, which included stock market indices such as NASDAQ 100, S\&P 500, Euronext 100, FTSE 100 and NIKKEI 225, show that bitcoin can be preferred as a protection tool against shocks in economic uncertainty. Karanasos and Yfanti (2020) examines the provocative effects of UK Policy Uncertainty as well as global credit and commodity factors spreading across European financial markets. The findings, on the other hand, cause the high uncertainty in the UK, the leverage ratio of the credit and commodity markets on the actual volatility of the European stock markets, and their increase with a significant effect on the global macro effects.

\section{Data and Methodology}

Ethics of research and publication were followed in this study, which did not require permission from the ethics committee and / or legal / special permission. Monthly data of the European EPU index and BIST 100 index between February 1988 and May 2019 were used in the study. EPU index is an index that shows the uncertainties in the economic policies of countries. The EPU index calculated with the method developed in the study of Baker et al. (2016) is calculated for 23 countries. In addition, the European EPU index and the global EPU index representing the European continent are also calculated. EPU index was obtained from www.policyuncertainty.com website.

Determining whether the variables are stationary is the first step of the process. Whether the data are stationary or not is important in the analysis process and unit root tests are used to test the stationarity. Yule (1926) states that to be able to use financial data in analysis, the data must be stable. Stationarity means that the average and variance of the relevant data will remain constant over time (Asteriou and Hall, 2011, p. 335). In the study of Granger and Newbold (1974), it was stated that spurious regression problem may occur when non-stationary data sets are used in analysis. Nelson and Plosser (1982) stated that stationary data sets should be used in 
standard statistical methods. The most popular unit root tests, Extended Dickey Fuller (ADF) and Phillips Perron (PP) tests were applied to test the stationarity of data sets. ADF unit root test was developed in Dickey and Fuller (1981) study and PP test was developed in Phillips and Perron (1988) study. The ADF test is applied under an assumption that error terms are of constant variance and independence (Asteriou and Hall, 2011, p. 345). PP test, which has more flexible assumptions than the ADF test, is accepted to be relatively more trustable (Fabozzi, Focardi, Rachev and Arshanapalli, 2014, p. 197).

The existence of a long-term interaction among variables is reached by cointegration tests (Gujarati and Porter, 2012, p. 762). In order to perform the cointegration test, the data must contain unit root at the level, in other words, it should not be stationary and be integrated at the same level. In order for a cointegration relationship to occur between two variables, the error terms of the data must be stationary (Dikmen, 2012, p. 321).

Johansen cointegration test was developed in the study of Johansen (1988) and Johansen and Juselius (1990) and is based on the VAR analysis, which includes the level of the variables at the same level and the lag value of stationary series (Tarı and Yildırım, 2009, p. 100). VAR model can be expressed as in equation (1) (Greene, 2012, p. 1006).

$$
y_{t}=\Gamma_{1} y_{t-1}+\Gamma_{2} y_{t-2}+\cdots+\Gamma_{p} y_{t-p}+\varepsilon_{t}
$$

Trace statistics are used to test the cointegration between variables included in the analysis. In the trace statistics test, the null hypothesis, which states that there are at most " $r$ " cointegration vector, is tested. Trace statistics can be shown as (2) in the following equation (Greene, 2012, p. 1007).

$$
\gamma_{t r}=-T \sum_{i=r+1}^{M} \ln \left[1-\left(r_{i}^{*}\right)^{2}\right]
$$

FMOLS developed in Phillips and Hansen (1990) study and DOLS tests developed in the study of Saikkonen (1991) and Stock and Watson (1993) are the most used tests in estimation of cointegration coefficients. While FMOLS test is a nonparametric approach, DOLS test is a parametric approach. In the FMOLS method, interaction among the constant term, the error term and the differences of the independent variables is taken into account. In the DOLS method, the autocorrelation problem is corrected by adding the delayed first differences of the data to the model. FMOLS and DOLS estimators are expressed by the following equations (3 and 4), respectively (Breitung and Pesaran, 2008, p. 310; Narayan and Wong, 2009, p. 2774)

$$
\begin{gathered}
y_{t}=\dot{\beta} x_{t}+\sum_{k=-\infty}^{\infty} \dot{\gamma}_{k} \Delta x_{t-k}+\mu_{t} \\
y_{t}=\alpha_{i t}+\beta x_{t}+\varepsilon_{t} \\
x_{t}=x_{t-1}+\varepsilon_{t}
\end{gathered}
$$

$\beta$ : Cointegration vector, $\mathrm{y}_{-} \mathrm{t}$ : dependent variable, $\mathrm{x}_{-} \mathrm{t}$ : independent variable, $\mu$ : refers to the term error.

In Engle and Granger (1987) study, prorvided that the time series that are not stationary but at the level of I (1) are cointegrated, VECM can be applied to examine both the short and long term dynamics of the series. 
Conventional ECM for Cointegrated series (Engle and Granger, 1987):

$$
\Delta y_{t}=\beta_{0}+\sum_{i=1}^{n} \beta_{i} \Delta y_{t-i}+\sum_{i=1}^{n} \delta_{i} \Delta x_{t-i}+\varphi z_{t-1}+\mu_{t}
$$

$\mathrm{z}$ is the error correction term and it is the OLS residuals from the following long-range cointegrating regression:

$$
y_{t}=\beta_{0}+\beta_{1} x_{t}+\varepsilon_{t}
$$

and it is defined as

$$
z_{t}=E C T_{t-1}=y_{t-1}-\beta_{0}-\beta_{i} x_{t-1}
$$

The term error correction is a situation where the last-term deviation from the long range balance affects the short range dynamics of the dependent variables. Therefore, the ECT coefficient, $\phi$, is the rate of adjustment because it is an indicator that measures the rate at which $\mathrm{Y}$ returns to equilibrium after a change in $\mathrm{X}$.

In the VECM, the coefficient of the delayed value of the error terms is expected to be statistically significant. The significance of the mentioned coefficient indicates that there is causality between the series (Aktaş and Yılmaz, 2008; Karagol, Erbaykal and Ertugrul, 2006).

\section{Findings}

As can be seen in the table below, the descriptive statistics of BIST 100 index and EPU index were reached in the study.

Table 1. Descriptive Statistics

\begin{tabular}{lcccc}
\hline Variable & Mean & Min. & Max. & Standard Dev. \\
\hline BIST 100 & $32.373,02$ & 3,74 & $119.528,8$ & $34.247,95$ \\
lnBIST 100 & 8,5321 & 1,3190 & 11,6913 & 3,0458 \\
EPU & 128,41 & 41,0143 & 433,2775 & 62,0881 \\
lnEPU & 4,7513 & 3,7139 & 6,0714 & 0,4514 \\
\hline
\end{tabular}

When the descriptive statistics obtained are analyzed, the volatility of the BIST100 index is greater than the volatility of the EPU index. On the other hand, in Table 2, unit root test results can be reached for these two variables.

Table 2. Unit Root Test Results

\begin{tabular}{lcccc}
\hline \multirow{2}{*}{ Variables } & \multicolumn{2}{c}{ ADF } & \multicolumn{2}{c}{ PP } \\
\cline { 2 - 5 } & Constant & $\begin{array}{l}\text { Constant } \\
\text { \& Trend }\end{array}$ & Constant & $\begin{array}{c}\text { Constant } \\
\text { \& Trend }\end{array}$ \\
\hline $\ln$ BIST 100 & -2.6721 & -0.9178 & -2.6412 & -0.9446 \\
$\Delta \operatorname{lnBIST} 100$ & $-18.3826^{*}$ & $-9.0828^{*}$ & $-18.4172^{*}$ & $-18.6849^{*}$ \\
$\ln \mathrm{EPU}$ & -2.0196 & -3.1387 & $-5.4451^{*}$ & $-8.3193^{*}$ \\
$\Delta \operatorname{lnEPU}$ & $-27.1804^{*}$ & $-27.1438^{*}$ & $-27.4983^{*}$ & $-27.4605^{*}$ \\
\hline
\end{tabular}

* Significant at $1 \%$ significance level.

According to findings of unit root test in Table 2, it can be seen that the relevant variables contain unit root at the level, while the given is stationary in the difference series. According to 
the results, Johansen Cointegration analysis can be performed using the level values of the variables. The results of the cointegration test conducted in order to determine the long-run interaction among variables are presented in Table 3.

Table 3. Johansen Cointegration Test Results

\begin{tabular}{llcc}
\hline $\mathbf{H}_{\mathbf{0}}$ & $\mathbf{H}_{\mathbf{1}}$ & Trace Statistics & $\begin{array}{c}\text { Maximum Eigenvalue } \\
\text { Statistics }\end{array}$ \\
\hline $\mathrm{r}=0$ & $\mathrm{r} \geq 1$ & $33.8645^{*}$ & $24.3010^{*}$ \\
$\mathrm{r} \leq 1$ & $\mathrm{r} \geq 2$ & 9.5634 & 9.5634 \\
\hline
\end{tabular}

* Significant at $1 \%$ significance level.

According to results of the cointegration test in Table 3, it has been determined that there is one cointegration vector among the variables. According to these results, it can be stated that there is a long-run relationship between the BIST 100 index and the EPU index. The related result coincides with the results of Tiryaki and Tiryaki (2019) study in the literature. Test results for the Error Correction Prediction Model are given in Table 4.

Table 4. Error Correction Model Forecast Results

\begin{tabular}{lccc}
\hline $\begin{array}{l}\text { Dependent } \\
\text { Variable }\end{array}$ & $\begin{array}{c}\text { Independent } \\
\text { Variable }\end{array}$ & Coefficient & t statistics \\
\hline \multirow{3}{*}{$\Delta \ln B I S T 100$} & $\Delta \ln$ EPU & -0.0649 & $-2.5335^{* *}$ \\
& $\mathrm{EC}_{\mathrm{t}-1}$ & -0.0058 & $-2.1437^{* *}$ \\
& $\mathrm{C}$ & 0.0253 & $3.7613^{*}$ \\
\hline
\end{tabular}

$* 1 \%$ is significant at the $* * 5 \%$ significance level.

According to the results in Table 4, it is seen that there is a negative and significant relationship between the EPU index and the BIST 100 index. As the uncertainties in European economic policies increase, it shows that this has a negative effect on the BIST 100 index. In times of increased uncertainty, investors postpone their investment decisions due to their wait and see policy. For this reason, stock market investors also delay their investments in stocks. Therefore, stocks are expected to be negatively affected by this situation. The term lagged error correction indicates that the deviation between the real returns of the BIST 100 index and the long-term returns disappears by $0.6 \%$ each month. The respective deviations $(1 / 0.6=1.6)$ will reach the long-term equilibrium again in about a month and a half. Table 5 shows the results of VECM analysis.

Table 5. VECM Forecast Results

\begin{tabular}{lcc}
\hline Dependent Variable & $\begin{array}{c}\text { Short Term } \\
\text { (Wald Test - Chi-square) }\end{array}$ & $\begin{array}{c}\text { Long Term } \\
\text { ECT }_{\text {t-1 }}\end{array}$ \\
\hline$\Delta \ln B$ IST 100 & $5.5666^{* *}$ & $-0.0077^{*}$ \\
\hline$* 1 \%$ is significant at the $* * 10 \%$ significance level. &
\end{tabular}

According to the VECM analysis results, ECTt-1 was found to be statistically significant and negative. According to this result, it has been determined that there is a long-term causality relationship from the EPU index to the BIST 100 index. Since the Wald test result is statistically significant, it has been determined that there is a short-term causality relationship from the EPU 
index to the BIST 100 index. Table 6 shows the cointegration coefficient estimators FMOLS and DOLS test results showing the direction of the relationship among variables.

Table 6. FMOLS and DOLS Test Results

\begin{tabular}{lll}
\hline \multicolumn{3}{c}{ FMOLS Results } \\
\hline Coefficient & t-statistics \\
\hline $\ln E P U$ & -1.5386 & $-3.7782^{*}$ \\
\hline & DOLS Results & \\
\hline $\operatorname{lnEPU}$ & Coefficient & t-statistics \\
\hline$*$ Significant at $1 \%$ significance level. & -1.5772 & $-3.2543^{*}$ \\
\hline
\end{tabular}

According to the FMOLS and DOLS test results, it was determined that the EPU index negatively and significantly affected the BIST 100 index. These findings obtained are similar to the findings of Kang and Ratti (2013), Li et al. (2015), Baker et al. (2016), Chen et al. (2017), Hu et al. (2018), Korkmaz and Güngör (2018), Chiang (2019) and Tiryaki and Tiryaki (2019) studies.

\section{Conclusion and Recommendation}

Uncertainties are one of the important factors that influence investors' investment decisions. In an environment of uncertainty, investors will not want to take risks and may postpone their investment decisions until the uncertainties disappear.

Therefore, in this paper, the impact of the European EPU on the BIST 100 index was tested. The long-term relationship was tested with the Johansen cointegration analysis. FMOLS and DOLS cointegration tests were applied to determine the direction of the long-term relationship. VECM test was used for short and long term causality relationship. The short and long-term relationship between BIST100 index and EPU index was also investigated by VECM.

Findings obtained It has been reached that there is a long-run interaction between BIST 100 and EPU index. On the other hand, it was found that the independent variable EPU index has a negative effect on the BIST 100 index. When the causality between EPU and BIST100 index is examined, it is found that there is a relationship from the change in the EPU index to the change in the BIST 100 index in the short and long-term. As a result of the investigation, it can be suggested that investors who will invest in the BIST 100 index should follow other indicators representing uncertainties and risks, such as the EPU index, which is an indicator of uncertainties in European economic policies. Performing analysis in terms of developed and developing countries in other studies will contribute to the literature such as generalizing the results.

\section{Researchers' Contribution Rate Statement}

The authors declare that they have contributed equally to the article.

Conflict of Interest Statement

There is no potential conflict of interest in this study. 


\section{References}

Akdağ, S. (2020). Ekonomi politikalarındaki belirsizliklerin güven endeksleri üzerindeki etkisi [The effects of uncertainties in economic policy on confidence indices]. Maliye ve Finans Yazlarl, 113, 139-152. https://doi.org/10.33203/mfy.574113

Aktaş, C. and Yılmaz, V. (2008). Causal relationship between oil consumption and economic growth in Turkey. Kocaeli Üniversitesi Sosyal Bilimler Enstitüsü Dergisi 15, 45-55. Retrieved from https://dergipark.org.tr/en/pub/uiibfd

Asteriou, D. and Hall, S. G. (2011). ARIMA models and the Box-Jenkins methodology. Applied Econometrics, 2(2), 265-286. doi:10.1057/978-1-137-41547-9_13

Baker, S. R., Bloom, N. and Davis, S. J. (2016). Measuring economic policy uncertainty. The Quarterly Journal of Economics, 131(4), 1593-1636. https://doi.org/10.1093/qje/qjw024

Bayar, Y. and Aytemiz, L. (2015). Economic policy uncertainty and stock market returns in selected Eurozone countries. Journal of Applied Economic Sciences, 31, 152-158. https://www.ceeol.com/

Bernanke, B. S. (1983). Irreversibility, uncertainty, and cyclical investment. The Quarterly Journal of Economics, 98(1), 85-106. https://doi.org/10.2307/1885568

Bloom, N. (2009). The impact of uncertainty shocks. Econometrica, 77(3), 623-685. https://doi.org/10.3982/ECTA6248

Breitung J. and Pesaran M. H. (2008) Unit roots and cointegration in panels. In L. Mátyás and P. Sevestre (Eds.), The econometrics of panel data (pp. 279-322). Springer, Berlin, Heidelberg. https://doi.org/10.1007/978-3-540-75892-1_9

Cerda, R., Silva, Á. and Valente, J. T. (2018). Impact of economic uncertainty in a small open economy: The case of Chile. Applied $\quad$ Economics, 50(26), $2894-2908$. https://doi.org/10.1080/00036846.2017.1412076

Chen, J., Jiang, F., Liu, Y. and Tu, J. (2017). International volatility risk and Chinese stock return predictability. Journal of International Money and Finance, 70, 183-203. https://doi.org/10.1016/j.jimonfin.2016.08.007

Chiang, T. C. (2019). Empirical analysis of economic policy uncertainty and stock returns in Asian markets. In C-F. Lee and M-T. Yu (Eds.), Advances in pacific basin business, economics and finance (pp. 63-87). https://doi.org/10.1108/S2514-465020190000007004

Dickey, D. A. and Fuller, W. A. (1981). Likelihood ratio statistics for autoregressive time series with a unit root. Econometrica: Journal of the Econometric Society, 49(4), 1057-1072. https://doi.org/10.2307/1912517

Dikmen, N. (2012). Ekonometri: Temel kavramlar ve uygulamalar. Bursa: Dora Basım Yayım Dağ. Ltd. Şti.

Donadelli, M. (2015). Asian stock markets, US economic policy uncertainty and US macro-shocks. New Zealand Economic Papers, 49(2), 103-133. https://doi.org/10.1080/00779954.2014.890024

Engle, R. and Granger, C. W. J. (1987). Cointegration and error correction representation, estimation and testing. Econometrica, 55, 251-276. https://doi.org/10.2307/1913236

Fabozzi, F. J., Focardi, S. M., Rachev, S. T. and Arshanapalli, B. G. (2014). The basics of financial econometrics: Tools, concepts, and asset management applications. UK: John Wiley \& Sons, Inc.

Granger, C. W. J. and Newbold, P. (1974). Spurious regressions in econometrics. Journal of Econometrics, 2(2), 111-120. https://doi.org/10.1002/9780470996249

Greene, W. (2012). Econometric analysis (Seven edition). UK: Pearson Education Limited.

Gujarati, D. N. and Porter, D. C. (2012). Temel ekonometri (Çev. Ü. Şenesen ve G. Günlük-Şenesen). İstanbul: Literatür Yayıncılık. 
Hu, Z., Kutan, A. M. and Sun, P. W. (2018). Is US economic policy uncertainty priced in China's Ashares market? Evidence from market, industry, and individual stocks. International Review of Financial Analysis, 57, 207-220. https://doi.org/10.1016/j.irfa.2018.03.015

Jeon, J. H. (2019). Uncertainty and manufacturing stock market in Korea. Journal of Industrial Distribution \& Business, 10(1), 29-37. https://doi.org/10.13106/ijidb.2019.vol10.no1.29

Johansen, S. (1988). Statistical analysis of cointegration vector. Journal of Economic Dynamics and Control, 12(2-3), 231-254. https://doi.org/10.1016/0165-1889(88)90041-3

Johansen, S. and Juselius, K. (1990). Maximum likelihood estimation and inference on cointegration with applications to the demand for money. Oxford Bulletin of Economics and Statistics, 52(2), 169210. Retrieved from https://digidownload.libero.it

Kang, W. and Ratti, R. A. (2013). Oil shocks, policy uncertainty and stock market return. Journal of International Financial Markets, Institutions and Money, 26, 305-318. https://doi.org/10.1016/j.intfin.2013.07.001

Karagol, E., Erbaykal, E. and Ertugrul, H. M. (2006, May). Oil consumption and GNP relationship in Turkey: An empirical study. In O. Esen and A. Ogus (Eds.), International Conference on Human and Economic Resources Proceedings Book (pp. 363-369). Paper presented at the International Conference on Human and Economic Resources. Izmir University of Economics \& Suny Cortland. Retrieved from http://eco.ieu.edu.tr/wp-content/proceedings/2006/2006.pdf

Karanasos, M. and Yfanti, S. (2020). On the macro-drivers of realized volatility: the destabilizing impact of UK policy uncertainty across Europe. The European Journal of Finance, 26(12), 1146-1183. https://doi.org/10.1080/1351847X.2020.1732437

Korkmaz, Ö. ve Güngör, S. (2018). Küresel ekonomi politika belirsizliğinin Borsa İstanbul'da işlem gören seçilmiş endeks getirileri üzerindeki etkisi [The impact of global economic policy uncertainty on stock returns of selected index traded on Istanbul stock exchange]. Anemon Muş Alparslan Üniversitesi Sosyal Bilimler Dergisi, 6(Özel Say1: ICEESS’18), 211-219. https://doi.org/10.18506/anemon.452749

Li, X. M., Zhang, B. and Gao, R. (2015). Economic policy uncertainty shocks and stock-bond correlations: Evidence from the US market. Economics Letters, 132, 91-96. https://doi.org/10.1016/j.econlet.2015.04.013

Liu, B. (2010). Uncertainty theory: A branch of mathematics. In J. Kacprzyk (Ed.), Uncertainty theory (pp. 1-79). Springer, Berlin, Heidelberg. https://doi.org/10.1007/978-3-642-13959-8_1

Matkovskyy, R., Jalan, A. and Dowling, M. (2020). Effects of economic policy uncertainty shocks on the interdependence between Bitcoin and traditional financial markets. The Quarterly Review of Economics and Finance, 77, 150-155. https://doi.org/10.1016/j.qref.2020.02.004

Narayan, P. K. and Wong, P. (2009). A panel data analysis of the determinants of oil consumption: The case of Australia. Applied Energy, 86(12), 2771- 2775. https://doi.org/10.1016/j.apenergy.2009.04.035

Nelson, C. R. and Plosser, C. R. (1982). Trends and random walks in macroeconomic time series: Some evidence and implications. Journal of Monetary Economics, 10(2), 139-162. https://doi.org/10.1016/0304-3932(82)90012-5

Phillips, P. C. B. and Hansen, B. E. (1990). Statistical inference in instrumental variables regression with I(1) processes. The Review of Economic Studies, 57(1), 99-125. https://doi.org/10.2307/2297545

Phillips, P. C. B. and Perron, P. (1988). Testing for a unit root in time series regression. Biometrika, 75(2), 335-346. https://doi.org/10.1093/biomet/75.2.335

Saikkonen, P. (1991). Asymptotically efficient estimation of cointegration regressions. Econometric Theory, 7(1), 1-21. Retrieved from https://www.jstor.org/

Stock, J. H. and Watson, M. W. (1993). A simple estimator of cointegrating vectors in higher order integrated systems. Econometrica, 61(4), 783-820. https://doi.org/10.2307/2951763 
Tarı, R. ve Yıldırım, D. Ç. (2009). Döviz kuru belirsizliğinin ihracata etkisi: Türkiye için bir uygulama [The effect of exchange rate on export: An analysis for Turkey]. Yönetim ve Ekonomi: Celal Bayar Üniversitesi İktisadi ve İdari Bilimler Fakültesi Dergisi, 16(2), 95-105. Retrieved from https://dergipark.org.tr/tr/pub/yonveek/

Tiryaki, H. N. and Tiryaki, A. (2019). Determinants of Turkish stock returns under the impact of economic policy uncertainty. Uluslararast İktisadi ve İdari Incelemeler Dergisi, 22, 147-162. https://doi.org/10.18092/ulikidince.424369

Wu, T. P., Liu, S. B. and Hsueh, S. J. (2016). The causal relationship between economic policy uncertainty and stock market: A panel data analysis. International Economic Journal, 30(1), 109122. https://doi.org/10.1080/10168737.2015.1136668

Yule, G. U. (1926). Why do we sometimes get nonsense-correlations between time-series? - A study in sampling and the nature of time-series. Journal of the Royal Statistical Society, 89(1), 1-63. https://doi.org/10.2307/2341482 